\title{
Flow Cytometric Analysis of the Influence of Myosmine on the Cell Cycle
}

\author{
Borislava I. Boteva, ${ }^{a}$ Rada M. Mateva, ${ }^{a}$ Ivan A. Iliev, ${ }^{b}$ and Galina A. Gorneva ${ }^{\mathrm{a}, *}$ \\ ${ }^{a}$ Institute of Molecular Biology, Bulgarian Academy of Sciences, ul. Acad Bonchev 21, Sofia 1113, Bulgaria \\ ${ }^{\mathrm{b}}$ Institute for Experimental Morphology, Pathology and Anthropology with Museum (IEMPAM), \\ ul. Acad Bonchev 25, Sofia1113, Bulgaria
}

RECEIVED OCTOBER 7, 2010; REVISED DECEMBER 8, 2010; ACCEPTED DECEMBER 10, 2010

\begin{abstract}
Myosmine (3-(1-pyrrolin-2-yl)pyridine) is an alkaloid found in tobacco as well as various staple foods, fruits and vegetables. Myosmine has recently been suspected to be a tobacco-independent carcinogenic source. Using cell flow cytometry, we have examined the influence of myosmine on the cell cycle of murine erythroleukemia (MEL) cells in vitro and have compared this with its effects on murine bone marrow cells in vivo. Myosmine at low concentrations inhibited cell proliferation dose dependently; while at concentrations close to $300 \mu \mathrm{mol} \mathrm{dm}{ }^{-3}$ it acted in a cytostatic fashion, that is, it increased the percen-

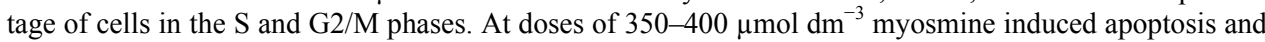
the hypoploid fraction. In vivo intraperitoneal injection of mice with $100 \mathrm{mg} / \mathrm{kg}$ of myosmine resulted in a statistically significant increase in the percentage of cells in S phase; i.e. from 13.75 to $18.22 \%$. The percentage of bone marrow cells in the G2/M phase increased from 6.79 to $8.93 \%$ in treated mice compared to controls. All of these results are in agreement with the hypothesis that myosmine possesses genotoxic potential. (doi: 10.5562/cca1767)
\end{abstract}

Keywords: myosmine, cytotoxicity, cell cycle, apoptosis, bone marrow

\section{INTRODUCTION}

Myosmine, 3-(1-pyrrolin-2-yl)pyridine, as well as nicotine, is among the fully structurally characterized tobacco alkaloids. ${ }^{1}$ Unlike nicotine, myosmine is found in various commonly consumed foods such as nuts, vegetables, and fruits. ${ }^{2,3}$ It is not surprising therefore, that myosmine has also been detected in human toenail, plasma and saliva from normal controls. ${ }^{4}$ After nitrosation and/or peroxidation, myosmine gives rise to reactive pyridyloxobutylating species which are capable of forming pyridyloxobutylated DNA adducts. ${ }^{5-8}$ Nitrosation of myosmine also leads to the formation of the esophageal carcinogen $N^{\prime}$-nitrosonornicotine. ${ }^{5}$ Originally, nitrosonornicotine and 4-hydroxy-1-(3-pyridyl)-1butanone (HPB)-releasing adducts were thought to be highly tobacco-specific.

A number of scientists connect human intake of myosmine to the increase in incidence of esophageal adenocarcinoma in the Western world. ${ }^{9}$ In support of this hypothesis, there is data which shows that in sudden death victims HPB-releasing DNA adducts found in esophageal mucosa taken from close to the esophagogastric junction, were similar in quantity in smokers and nonsmokers. ${ }^{10}$ It was therefore hypothesized that a tobacco-independent source for these adducts might have been myosmine uptake from food. ${ }^{2,3,5,6}$

The genotoxicity of myosmine has been studied in a number of in vitro models. Comet assay studies have shown that myosmine induces DNA damage in nasal mucosa cells, human lymphocytes and in cell lines derived from human esophageal adenocarcinoma. ${ }^{11,12}$ In another investigation, the mutagenic potential of myosmine was demonstrated in human lymphocytes using the human lymphocyte hypoxanthine guanine phosphoribosyl transferase gene mutation assay. ${ }^{13}$

It has been shown that eukaryotic cells respond to DNA damage by inducing temporary cell cycle arrest at the $\mathrm{G} 1 / \mathrm{S}$ and $\mathrm{G} 2 / \mathrm{M}$ transition points; $;{ }^{14}$ these transient delays in cell cycle progression presumably allow time for repair and prevent the replication and segregation of damaged DNA templates. That is why it is interesting to investigate whether or not myosmine is also able to influence the cell cycle both in vitro and in vivo. As our

\footnotetext{
$\dagger$ Presented at the $10^{\text {th }}$ International Symposium and Summer School on Bioanalysis within the CEEPUS Network CII-HU-001004-0910, Zagreb, Croatia, July 2010.

* Author to whom correspondence should be addressed. (E-mail: galinagorneva@abv.bg)
} 
in vivo model we have chosen to study bone marrow cells because the generally accepted method for determining the carcinogenic potential of a substance is the mouse micronucleus assay, ${ }^{15}$ an assay which uses bone marrow polychromatic erythrocytes. In order to correctly interpret our in vivo results, it was logical to study the effect of myosmine in the closest possible in vitro model, and for this we chose Friend murine erythroleukemia cells, virally transformed erythroid precursors that are held in an immature and proliferating state. ${ }^{16}$ The metabolism of these cells is similar to that of the majority of proliferating hematopoietic cells in the bone marrow. ${ }^{17}$

\section{MATERIALS AND METHODS}

\section{Materials}

Myosmine was synthesized in the Institute of Molecular Biology, Bulgarian Academy Science (BAS), in accordance with the published method of Brandänge and Lindblom (1976). ${ }^{18}$ The product was found to be $99.9 \%$ pure; it's identity with commercial myosmine was confirmed by ultraviolet and infrared spectral analysis, gas chromatography and high pressure liquid chromatography. All other reagents were purchased from SigmaAldrich Chemie GmbH, Deisenhofen, Germany and were of analytical grade. The solutions needed for flow cytometric analysis were obtained from BD Bioscience.

\section{Cell Culture}

Murine erythroleukemia cells, clone F4N (virustransformed erythroid precursor cells) ${ }^{16}$ were cultured in Dulbecco's modified Eagle medium (Gibco) supplemented with $10 \%$ calf serum, and cultured in a $5 \%$ $\mathrm{CO}_{2}$ atmosphere at $37{ }^{\circ} \mathrm{C}$, and passed every day at a concentration of $5 \times 10^{5}$ cells $/ \mathrm{ml}$.

\section{Incubation with Myosmine and In Vitro Cytotoxicity Test}

An aliquot of $5 \times 10^{5}$ cells $/ \mathrm{ml}$ in the exponential phase of growth was incubated with myosmine in 24-well microtiter plates. After 24 or 48 hours of treatment with myosmine, the cells were counted hemocytometrically and prepared for cell cycle analysis. The number of dead cells was determined by staining with trypan blue. The mean \pm SD of triplicate determinations of viable cells was calculated. The fraction of cells undergoing apoptosis was determined using fluorescent microscopy with propidium iodide.

\section{Animals}

30-40 day-old BALB/c mice weighing 25-30 g were obtained from the National Center of Public Health Protection. They received proper care and were pro- vided with food and water ad libitum. Each group of 6 mice was treated with an intraperitoneal injection of various concentrations of myosmine diluted in sterile water and housed in a separate compartment. Experiments were performed in accordance with the guidelines for Care and Use of Laboratory Animals under work permit №11130007 of the Institute of Molecular Biology, Bulgarian Academy of Sciences.

\section{Bone Marrow}

Twenty four hours after their last treatment with myosmine, mice were killed by cervical dislocation. The left femur was removed and the bone marrow cavity was flushed with $1 \mathrm{ml}$ Hanks Balanced salt solution (HBSS). The extracted bone marrow was suspended in cold HBSS, and the cells were suspended in the solution by passing them through a $70 \mu \mathrm{m}$ nylon mesh (Cell Strainer, BD Falcon). Five mls of $70 \%$ ethanol was added dropwise to the cells while vortexing. Cells were stored at $-20{ }^{\circ} \mathrm{C}$ for 24 hours to fix.

\section{Cell Cycle Analysis}

After $24 \mathrm{~h}$ incubation with different concentrations of myosmine, the cells were harvested by centrifugation and resuspended in $0.5 \mathrm{ml}$ cold PBS. A quantity of $70 \%$ ethanol was added dropwise to the cells while vortexing. Cells were stored at $-20{ }^{\circ} \mathrm{C} 24$ hours to fix. Just before flow cytometric analysis (FACS) cells were spun down, washed with PBS and resuspended in propidium iodide (PI) staining solution containing $100 \mu \mathrm{g} / \mathrm{ml}$ RNase and $50 \mu \mathrm{g} / \mathrm{ml}$ PI. FACS analysis was performed on a FACSCalibur (Beckton Dikinson) using the FL3-A channel. A minimum of 10000 cells were analyzed from each cell sample and the resulting histograms were evaluated using WinMDI 2.9 software.

\section{Statistical Analysis}

The percentage of bone marrow cells in each phase of the cell cycle was expressed as the mean \pm SD. Differences between control and treated samples were analyzed for significance by Student's $t$ test. A P value of $<0.05$ indicated statistical significance.

\section{RESULTS AND DISCUSSION}

\section{In Vitro Cytotoxicity of Myosmine}

For this study we used mouse erythroleukemia cells, clone $\mathrm{F} 4 \mathrm{~N}$, in which several antitumor drugs have already been shown to readily trigger apoptosis. ${ }^{19,20}$ The growth inhibitory and cytotoxic effect of incubation of MEL cells with different concentrations of myosmine have been shown in Figure 1. The presence in the cell culture of concentrations of myosmine lower than 


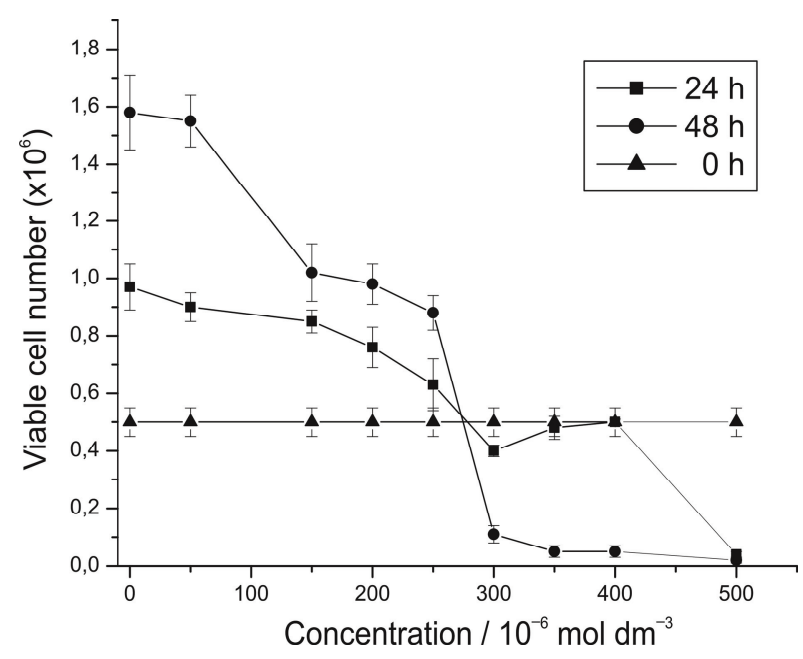

Figure 1. The dependence of the number of viable murine leukemia cells on myosmine concentration. Cells were treated with different concentrations of myosmine for 24 or 48 hours.

$50 \mu \mathrm{mol} \mathrm{dm}{ }^{-3}$ did not influence cell proliferaton, whereas higher concentrations of myosmine were found to inhibit cell growth. Twenty four hours after incubation with either 300 and $400 \mu \mathrm{mol} \mathrm{dm} \mathrm{dm}^{-3}$ myosmine a cytostatic effect was observed, and by 48 hours post treatment all cells were dead. This time course suggests programmed cell death rather than necrosis. To further clarify the mode of cell death, samples were examined by fluoroscent microscopy. Using this method as well as the comet assay, we have previously shown ${ }^{20}$ that apoptotic MEL cells exhibited changed morphology with fragmented condensed nuclei, while untreated control cells displayed uniform size and morphology. Myosmine, when added to cells in cytotoxic concentrations, induced apoptosis, and cells showed typical fragmented condensed nuclei, ghosts, and apoptotic bodies.

At concentrations of myosmine higher than 500 $\mu \mathrm{mol} \mathrm{dm} \mathrm{dm}^{-3}$ all cells appeared dead by 24 hours; some with typical apoptotic morphology, while others appeared necrotic. All of the cells were trypan blue positive, reflecting the fact that all had a defective external cell membrane. We have not presented photos of the apoptotic cells in this publication as they will published in a future article devoted to pro and anti apoptogenic action of myosmine.

\section{In Vitro Effect of Myosmine on Cell Cycle Progression}

To further analyze the nature of cell death, flow cytometric analysis was performed. If myosmine forms DNA adducts and the damage is significant enough, the cell cycle with be temporarily arrested, allowing the cells time for repair. In this study, MEL cells were incubated for 48 hours with different doses of myosmine (Figure

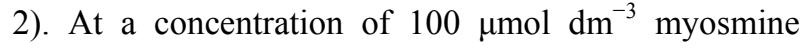

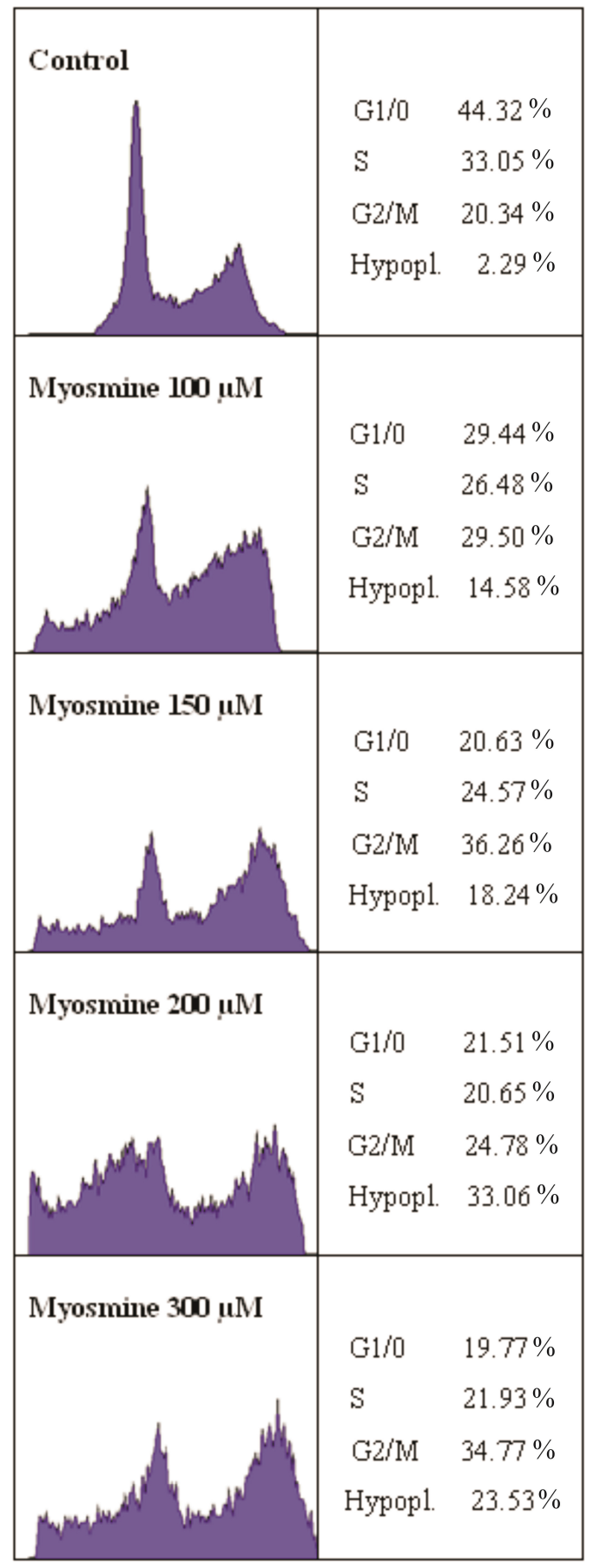

Figure 2. The influence of myosmine on cell cycle kinetics of murine leukemia cells. Cells were treated with different concentrations of myosmine for 48 hours. The histograms are from one typical experiment.

there was a decrease in the cell fraction in the G1/0 phase from 44 to $29 \%$ and an increase in G2/M from 20 to $29 \%$. After treatment with $150 \mu \mathrm{mol} \mathrm{dm}{ }^{-3}$ myosmine, the fraction of cells in $\mathrm{G} 2 / \mathrm{M}$ had increased significantly to $36 \%$. At $200 \mu \mathrm{mol} \mathrm{dm}{ }^{-3}$ myosmine the most characteristic change was a dramatic increase in the 
fraction of hypoploid cells to $33 \%$ compared to $2 \%$ in the control cells. According to the morphological analysis these were apoptotic cells. At $300 \mu \mathrm{mol} \mathrm{dm}{ }^{-3}$ there was an additional increase in the fraction of cells in $\mathrm{G} 2 / \mathrm{M}$ and a decrease in the number of hypoploid cells, probably a result of increased toxicity of higher concentrations of myosmine.

These results demonstrate that MEL cells responds to myosmine in the same way as they do to other genotoxic stressors, that is, by activating cell cycle checkpoints and by altering progression to the G2/M stage of the cell cycle, thus allowing the cells time to repair damage or move into apoptosis.

\section{In Vivo Effect of Myosmine on the Cell Cycle}

Former studies have shown that the $\mathrm{LD}_{50}$ for myosmine in rats is $190 \mathrm{mg} / \mathrm{kg}$ (i.p.) and $1875 \mathrm{mg} / \mathrm{kg}$ (p.o.). ${ }^{21}$ There is no available data on the acute toxicity of myosmine in mice. Therefore our first task was to find out the maximal tolerable dose of myosmine when given intraperitoneally to mice. Balb/C mice of 25-30 g were divided into groups of 2 animals and injected with myosmine in doses of $60,125,250,500 \mathrm{mg} / \mathrm{kg}$. Mice injected with either 500 or $250 \mathrm{mg} / \mathrm{kg}$ died within two minutes. When two mice were given $125 \mathrm{mg} / \mathrm{kg}$, one lived and the other died. At $60 \mathrm{mg} / \mathrm{kg}$, both animals lived. An additional two animals were then injected with $100 \mathrm{mg} / \mathrm{kg}$, and both lived. Therefore we concluded that the maximum tolerable dose was approximately $100 \mathrm{mg} / \mathrm{kg}$. This does was then used in the in vivo experiments.

The cell cycle distribution in bone marrow was studied $24 \mathrm{~h}$ after a single injection of $100 \mathrm{mg} / \mathrm{kg}$ myosmine (Table 1). Control mice were injected with a similar quantity of sterile water. There was a statistically significant increase in the percentage of cells in $\mathrm{S}$ phase (i.e. from 13.75 to $18.22 \%$ ) and in the $\mathrm{G} 2 / \mathrm{M}$ phase from 6.79 to $8.93 \%$ in the bone marrow isolated from treated mice compared to that of controls. It is likely that the in vivo effects were much less pronounced than the in vitro because only a portion of the bone marrow cells would have been in a proliferating state, while the remainder of the cells would have been in the G0/G1 phase. There are no studies providing

Table 1. Cell cycle phase distribution in bone marrow of control and myosmine treated mice.

\begin{tabular}{lccc}
\hline BONE & G0/G1 & $\mathrm{S}$ & G2/M \\
MARROW & & & \\
\hline control & $79.76 \pm 2.88$ & $13.75 \pm 1.35$ & $6.79 \pm 1.86$ \\
$100 \mathrm{mg} / \mathrm{kg}$ & $73.45 \pm 5.99$ & $18.22 \pm 4.03$ & $8.93 \pm 2.98$ \\
\hline
\end{tabular}

Data are expressed as means \pm SD of the proportion of cells in each cell-cycle phase. evidence for the accumulation of myosmine or myosmine's carcinogenic intermediates in bone marrow. In this study we have therefore acquired additional confirmation that myosmine or its metabolites reaches the bone marrow and influences cell division.

\section{CONCLUSION}

Our investigation has shown the ability of myosmine to inhibit cell proliferation and to alter cell cycle kinetics. The mode of cytotoxic action depends on the concentration of myosmine: at low concentrations it inhibited cell proliferation dose dependently; at concentrations close to $300 \mu \mathrm{mol} \mathrm{dm}{ }^{-3}$ myosmine acts in a cytostatic fashion, that is, increasing the percentage of cells in the $\mathrm{S}$ and $\mathrm{G} 2 / \mathrm{M}$ phases. At 350-400 $\mu \mathrm{mol}$ $\mathrm{dm}^{-3}$, myosmine induces apoptosis and the hypoploid fraction. In vivo treatment of mice with myosmine resulted in an increased percentage of bone marrow cells in S and G2/M phases, the same effect as was found in vitro. All of these results are in agreement with the hypothesis that myosmine possesses genotoxic potential.

Acknowledgements. We thank Prof. Elmar Richter for his continuous interest in this work and for helpful discussions, and Dr. Wolfgang Zwickenpflug for the HPLC analysis of myosmine and Rumyana Gugova for the synthesis of myosmine. This work was supported by grant no. TK-L-1608/06 from the National Fund for Scientific Research from the Bulgarian Ministry of Education and Sciences and CEEPUS II HU-0010.

\section{REFERENCES}

1. R. A. W. Johnstone and J. R. Plimmer, Chem. Rev. 59 (1959) 885-936.

2. W. Zwickenpflug, M. Meger, and E. Richter, J. Agric. Food Chem. 46 (1998) 2703-2706.

3. S. Tyroller, W. Zwickenpflug, and E. Richter, J. Agric. Food Chem. 50 (2002) 4909-4915.

4. K. Schütte-Borkovec, C. W. Heppel, A. K. Heling, and E. Richter, Biomarkers 14 (2009) 278-284.

5. W. Zwickenpflug, J. Agric. Food Chem. 48 (2000) 392-394.

6. E. Richter, D. Schlöbe, D. Hölzle, and J. Wilp, Naunyn Schmiedebergs Arch. Pharmacol. 365 (2002) R545.

7. J. Wilp, W. Zwickenpflug, and E. Richter, Food Chem. Toxicol. 40 (2002) 1223-1228.

8. W. Zwickenpflug and S. Tyroller, Chem. Res. Toxicol. 19 (2006) 150-155.

9. E. Bollschweiler, E. Wolfgarten, C Gutschow, and A. H. Hölscher, Cancer 92 (2001) 549-555.

10. D. Schlöbe, D. Hölzle, D. Hatz, L. Meyer, A. R. Tricker, and E. Richter, Toxicology 245 (2008) 154-161.

11. N. H. Kleinsasser, B. C. Wallner, U. A. Harreus, W. Zwickenpflug, and E. Richter, Toxicology 192(2-3) (2003) 171-177.

12. S. Vogt, K. Fuchs, and E. Richter, Toxicology 222 (2006) 71-79. 
13. J. B. Havla, C. E. Hill, S. Z. Abdel-Rahman, and E. Richter, Food and Chemical Toxicology 47 (2009) 237-241.

14. L. H. Hartwell and T.A. Weinert, Science 246 (1989) 629-634.

15. D. J. Tweats, D. Blakey, R. H. Heflich, A. Jacobs, S. D. Jacobsen, T. Morita, T. Nohmi, M. R. O’Donovan, Y. F. Sasaki, T. Sofuni, and R. Tice, Mutat. Res. 627 (2007) 92-105.

16. S. K. Dube, I. B. Pragnell, N. Kluge, G. Gaedicke, G. Steinheider, and W. Ostertag, Proc. Natl. Acad. Sci. USA 72 (1975) 1863-1867.
17. J. Chen, C. S. Kremer, and T. P. Bender, Oncogene 21 (2002) 1859-1869.

18. S. Brandänge and L. Lindblom, Acta Chem. Scand. 30 (1976) 39.

19. G. A. Gorneva and E. Golovinsky, Nova Acta Leopoldina 87(329) (2003) 183-189.

20. D. Kushev, G. Gorneva, S. Taxirov, N. Spassovska, and K. Grancharov, Biol. Chem. 380 (1999) 1287-1294.

21. A. M. Ambrose and F. DeEds, Proc. Soc. Exp. Biol. Med. 63 (1946) 423-424. 